\title{
Salicylic Acid as a Tolerance Inducer of Drought Stress on Sunflower Grown in Sandy Soil
}

\author{
Mohamed E. El-Bially ${ }^{1}$ Hani S. Saudy ${ }^{1}$ (D) · Fadl A. Hashem² · Yasser A. El-Gabry' • Mostafa G. Shahin'
}

Received: 3 December 2021 / Accepted: 8 February 2022 / Published online: 8 March 2022

(c) The Author(s) 2022

\begin{abstract}
Agricultural water rationalization expressed in irrigating the plants below their requirements became a significant strategy in crop water management. However, reduction in crop productivity under low water supply is realized. Therefore, the current study aimed to diminish sunflower yield losses associated with deficit irrigation using salicylic acid (SA). During two seasons of 2019 and 2020 at El Nubaria region, El Behaira Governorate, Egypt, combinations of three irrigation regimes (100, 85 and $70 \%$ of crop evapotranspiration, denoted $\mathrm{WR}_{100 \%}$, $\mathrm{WR}_{85 \%}$, and $\mathrm{WR}_{70 \%}$, respectively), and three levels of SA $\left(0.0,0.5\right.$, and $1 \mathrm{mM}$. abbreviated as $\mathrm{SA}_{0.0}, \mathrm{SA}_{0.5}$, and $\mathrm{SA}_{1.0}$, respectively) on sunflower plants performance were evaluated. Treatments were arranged in a strip-plot design with three replicates. Findings revealed that treated sunflower plants with $\mathrm{WR}_{100 \%} \times \mathrm{SA}_{1.0}$ contained the highest amounts of total chlorophyll and carotenoids as well as the lowest proline content. Seed yield of $\mathrm{WR}_{100 \%} \times \mathrm{SA}_{1.0}$ treatment was higher than that of $\mathrm{WR}_{70 \%} \times \mathrm{SA}_{0.0}$ by $109.7 \%$ in the first season and $125.9 \%$ in the second one. As averages of the two seasons, $\mathrm{SA}_{0.5}$ and $\mathrm{SA}_{1.0}$ lowered the reductions in seed yield from $21.0 \%$ to 15.8 and $14.4 \%$ as well as $46.2 \%$ to 40.8 and $40.1 \%$ under $\mathrm{WR}_{85 \%}$ and $\mathrm{WR}_{70 \%}$, respectively, compared to the farmer common practice $\left(\mathrm{WR}_{100 \%} \times \mathrm{SA}_{0.0}\right)$. $\mathrm{WR}_{100 \%} \times \mathrm{SA}_{1.0}$ for iodine value as well as $\mathrm{WR}_{100 \%} \times \mathrm{SA}_{1.0}$ and $\mathrm{WR}_{100 \%} \times \mathrm{SA}_{0.5}$ for seed oil \% were recorded the highest. Application of $\mathrm{WR}_{100 \%} \times \mathrm{SA}_{1.0}$ and $\mathrm{WR}_{100 \%} \times \mathrm{SA}_{0.5}$ were the effective combinations for ameliorating water use efficiency. In conclusion, involving salicylic acid in irrigation programs of sunflower became a decisive action to save water and alleviate the yield losses resulting from drought stress.
\end{abstract}

Keywords Deficit water $\cdot$ Economic yield $\cdot$ Irrigation management $\cdot$ Oil seed crops $\cdot$ Plant hormones $\cdot$ Plant pigments

Hani S. Saudy

hani_saudy@agr.asu.edu.eg

1 Agronomy Department, Faculty of Agriculture, Ain Shams University, Hadayek Shoubra, P.O. Box 68, 11241 Cairo, Egypt

2 Central Laboratory for Agricultural Climate, Agricultural Research Center, P.O. Box 12411, Giza, Egypt 


\section{Einsatz von Salicylsäure zur Erhöhung der Trockenheitstoleranz bei Sonnenblumen in sandigen Böden}

\section{Zusammenfassung}

Die Rationierung von Wasser in der Landwirtschaft, d.h. die Bewässerung von Pflanzen unter ihrem Bedarf, wurde zu einer wichtigen Strategie im Wassermanagement. Bei geringer Wasserversorgung kommt es jedoch zu einer Verringerung der Pflanzenproduktivität. Die vorliegende Studie zielte daher darauf ab, die mit Defizitbewässerung verbundenen Ertragseinbußen bei Sonnenblumen durch den Einsatz von Salicylsäure (SA) zu verringern. In den Jahren 2019 und 2020 wurden in der Region El Nubaria im Gouvernement El Behaira, Ägypten, Kombinationen aus drei Bewässerungsregimen (100, 85 und $70 \%$ der Evapotranspiration der Pflanzen, abgekürzt $\mathrm{WR}_{100 \%}$, WR $\mathrm{WR}_{85}$ bzw. WR $\left.\mathrm{WR}_{70}\right)$ und drei SA-Gehalten $(0,0,0,5$ und $1 \mathrm{mM}$, abgekürzt $\mathrm{SA}_{0,0}, \mathrm{SA}_{0,5}$ bzw. $\mathrm{SA}_{1,0}$ ) auf die Leistung von Sonnenblumenpflanzen untersucht. Die Behandlungen wurden in einem Strip-Plot-Design mit drei Wiederholungen angeordnet. Die Ergebnisse zeigten, dass behandelte Sonnenblumenpflanzen mit $\mathrm{WR}_{100 \%} \times \mathrm{SA}_{1,0}$ die höchsten Mengen an Gesamtchlorophyll und Carotinoiden sowie den niedrigsten Prolingehalt aufwiesen. Der Samenertrag der Behandlung $\mathrm{WR}_{100 \%} \times \mathrm{SA}_{1,0}$ war in der ersten Saison um 109,7\% und in der zweiten Saison um 125,9\% höher als der von $\mathrm{WR}_{70} \% \mathrm{SA}_{0,0}$. Im Durchschnitt der beiden Saisons verringerten $\mathrm{SA}_{0,5}$ und $\mathrm{SA}_{1,0}$ den Saatgutertrag von $21,0 \%$ auf 15,8 bzw. $14,4 \%$ sowie von $46,2 \%$ auf 40,8 bzw. $40,1 \%$ bei $\mathrm{WR}_{85} \%$ und $\mathrm{WR}_{70} \% \mathrm{im}$ Vergleich zur üblichen Praxis der Landwirte $\left(\mathrm{WR}_{100 \%} \times \mathrm{SA}_{0,0}\right)$. Bezüglich der Jodzahl wurde für $\mathrm{WR}_{100 \%} \times \mathrm{SA}_{1,0}$ der höchste Wert gemessen, bezüglich des Saatölanteils für $\mathrm{WR}_{100 \%} \times \mathrm{SA}_{1,0}$ und $\mathrm{WR}_{100 \%} \times \mathrm{SA}_{0,5} . \mathrm{WR}_{100 \%} \times \mathrm{SA}_{1,0}$ und $\mathrm{WR}_{100 \%} \times \mathrm{SA}_{0,5}$ waren die effektivsten Kombinationen zur Verbesserung der Wassernutzungseffizienz. Zusammenfassend lässt sich sagen, dass die Einbeziehung von Salicylsäure in Bewässerungsprogramme für Sonnenblumen eine entscheidende Maßnahme ist, um Wasser zu sparen und die durch Trockenstress bedingten Ertragsverluste zu verringern.

Schlüsselwörter Wassermangel · Wirtschaftlicher Ertrag · Bewässerungsmanagement · Ölsaaten · Pflanzenhormone · Pflanzenpigmente

\section{Introduction}

Global climate change has, undoubtedly, negative impact on crop growth and productivity. This is particularly acute in arid and semi-arid regions (Ahmadi and Souri 2018; Souri and Hatamian 2019), which suffer from water scarcity. Therefore, researchers are making continuous attempts to limit such adverse impacts (Saudy et al. 2020; El-Bially et al. 2022). In conjunction with global warming, drought is expected to become more frequent in many regions of the earth (Pokhrel et al. 2021). Drought is one of the major global factors that reduce yield in many crops worldwide (Nawaz et al. 2015). Due to the severity of various abiotic stresses such as drought, several concerns can threaten crop production (Anderson et al. 2020; Zulfiqar and Hancock 2020). Drought is considered one of the results associated climatic changes, thus it represents a major constraint to crop production universally (Farooq et al. 2012). It has been reviewed that exposure of plants to water stress leads to serious physiological and biochemical dysfunctions (Hayat et al. 2010; Makhlouf et al. 2022). Water deficit during critical growth periods of crops reduces their yield and quality, but, however, crops differ in their response to water stress at a given growth stage (El-Bially et al. 2018).

Sunflower (Helianthus annuus L.) is a high yielding oilseed crop and has the potential to bridge up the gap existing between consumption and domestic production of edible oil in Egypt. Sunflower is often reported as a drought-tolerant crop given its high capacity to extract water from the subsoil (Garcia-Vila and Fereres 2012). It has good potential for drought tolerance because of its well-developed root system and to withstand temporary wilting. However, sunflower production is greatly affected by drought (Siddique et al. 2020). It has been reported that sunflower productivity decreases with increasing drought levels (Erdem et al. 2006; Manivannan et al. 2007; Nezami et al. 2008; Siddique et al. 2020; Saudy et al. 2020). Periods of water deficit at any growth stage can cause canopy senescence with subsequent reduction in seed yield (Garcia-Vila and Fereres 2012). Sunflower productivity is mightily regulated by the availability of water and greatest yield losses manifest when water shortage occurs (Yawson et al. 2011).

Under abiotic stresses as drought, synthesizing of protectants by plants is a crucial act in inducing defense responses (Ozturk et al. 2021). In this respect, the endogenous biosynthesis of salicylic acid (SA), as a plant hormone (Smith et al. 2017), is affected by drought (La et al. 2019; Park et al. 2021). In various crops subjected to water deficit conditions, SA had the potentiality to regulate photosynthesis and antioxidant enzymes (Abdelaal 2015), as well as induce proline metabolisms, and antioxidant defense systems (Khan et al. 2014). Use of SA significantly mitigated the adverse impacts of drought and reduced lipid 
peroxidation (Kang et al. 2013). Therefore, environmental stressed-plant growth was enhanced by exogenous application of SA (Chavoushi et al. 2019; Abbaszadeh et al. 2020).

The relationship between the defense mechanism against drought and the protective impact of salicylic acid on sunflower still requires more investigations. We hypothesized that there is a definite rate of SA which could have the ability to change the fate of some plant physiological events to cope the different levels of drought stress (moderate or severe). Accordingly, the present study was carried out to investigate the effect of irrigation regimes on sunflower performance and for exploring to what extend salicylic acid at different rates can improve the drought tolerance.

\section{Material and Methods}

\section{Experimental Site and Crop Husbandry}

The present study was conducted at the Experimental Farm, Faculty of Agriculture, Ain Shams University, El Nubaria region, El Behaira Governorate, Egypt during the two seasons of 2019 and 2020. The experimental soil was sandy in texture with organic matter of $1.23 \%, \mathrm{pH} 7.85$, and EC $2.4 \mathrm{dS} \mathrm{m} \mathrm{m}^{-1}$. According to soil taxonomy (IUSS Working Group WRB 2015), the soil is order Entisols and suborder psamments. The area of the study belongs to arid regions with no rainfall and hot-dry in summer from May to August. Table 1 shows monthly mean weather factors, i.e. maximum and minimum air temperature, relative humidity, wind speed, and solar radiation for 2019 and 2020 seasons, obtained from Central Laboratory of Meteorology, Ministry of Agriculture and Land Reclamation, Egypt. The preceding crop was wheat in the two seasons of experimentation.

Sunflower seeds, cv. Sakha 53, were sown on May 19 and 21 in the first and second seasons, respectively. Seeds were sown in hills (3-5 seeds per hill) $20 \mathrm{~cm}$ apart on the ridge. At 15 days after sowing (DAS), plants were thinned to one plant per hill. Plants were irrigated through drip irrigation system using drippers of $2 \mathrm{~L} \mathrm{~h}^{-1}$ capacity.

\section{Experimental Treatments and Design}

In a strip-plot design with three replicates irrigation water levels were allocated in the vertical plots, whereas the horizontal plots were devoted to salicylic acid (SA) levels. The experimental unit area was $14 \mathrm{~m}^{2}$, involving five ridges each of $4 \mathrm{~m}$ long and $0.7 \mathrm{~m}$ wide. Irrigation water levels were 100,85 and $70 \%$ of crop evapotranspiration, representing well-watered, moderately water-stressed, and severely water-stressed conditions, and denoted $\mathrm{WR}_{100 \%}, \mathrm{WR}_{85 \%}$, and $\mathrm{WR}_{70 \%}$, respectively. The applied irrigation water had a $\mathrm{pH}$ of 7.53 and EC of $0.67 \mathrm{dS} \mathrm{m}^{-1}$. SA levels were $0.0,0.5$, and
$1 \mathrm{mM}$. abbreviated as $\mathrm{SA}_{0.0}, \mathrm{SA}_{0.5}$, and $\mathrm{SA}_{1.0}$, respectively. SA levels were sprayed twice, at 35 and 50 DAS. Tween-20 $\left(\mathrm{C}_{58} \mathrm{H}_{114} \mathrm{O}_{26}\right)$ is a trade name for polyoxyethylene (20) sorbitan monolaurate. The spray solution volume was $500 \mathrm{~L}$ $\mathrm{ha}^{-1}$ using a knapsack sprayer with one nozzle.

\section{Estimation of Water Requirements}

Crop evapotranspiration $\left(\mathrm{ET}_{\mathrm{c}}\right)$ was calculated by multiplying the reference crop evapotranspiration $\left(\mathrm{ET}_{\mathrm{o}}\right)$ by a crop coefficient $\left(\mathrm{K}_{\mathrm{c}}\right)$ according to Doorenbos and Pruitt (1977) using Eq. 1:

$\mathrm{ET}_{c}=\mathrm{K}_{c} \times \mathrm{ET}_{o}$

Where:

$\mathrm{ET}_{\mathrm{c}}$ : crop evapotranspiration $\left(\mathrm{mm} \mathrm{d}^{-1}\right)$

$\mathrm{K}_{\mathrm{c}}$ : crop coefficient (dimensionless).

$\mathrm{ET}_{\mathrm{o}}$ : reference crop evapotranspiration $\left(\mathrm{mm} \mathrm{d}^{-1}\right)$.

Moreover, the depth of applied irrigation water was calculated according to the Eq. 2 given by Vermeirer and Jopling (1984) as follows:

$\mathrm{AIW}=\frac{\mathrm{ET}_{c} \times \mathrm{I}}{\mathrm{E}_{a}(1-\mathrm{LR})}$

Where:

AIW: depth of applied irrigation water (mm)

$\mathrm{ET}_{\mathrm{c}}$ : $\quad$ crop evapotranspiration $\left(\mathrm{mm} \mathrm{day}^{-1}\right)$

I: irrigation intervals (day)

$\mathrm{E}_{\mathrm{a}}$ : irrigation system efficiency $(\%, 85 \%)$

LR: leaching requirements (since electrical conductivity of soil solution is low, LR was neglected)

The tested irrigation water levels were started after 30 DAS. The average of irrigation water amounts applied under different irrigation levels for sunflower during the two growing seasons are presented in Table 2.

\section{Data Recorded}

\section{Leaf Area and Biochemical Measurements}

At 65 DAS, five sunflower plants were chosen randomly from each plot to estimate leaf area according to Beadle (1993), and, in the same time, the $4^{\text {th }}$ leaves from the plant top were used for measuring each of total chlorophyll ( $\mathrm{mg} \mathrm{g}^{-1}$ fresh wt.), carotenoids ( $\mathrm{mg} \mathrm{g}^{-1}$ fresh wt.) according to Arnon (1949), and free proline content ( $\mu \mathrm{g} \mathrm{g}^{-1}$ fresh wt.) using the procedure described by Bates et al. (1973). Seed oil content (by extraction using Soxhlet Apparatus with hex- 
Table 1 Means monthly of climatic parameters and reference evapotranspiration (ET $)$ during sunflower growth and development at El Nubaria region (2019 and 2020 seasons)

\begin{tabular}{|c|c|c|c|c|c|c|c|c|c|c|c|c|}
\hline \multirow[t]{3}{*}{ Month } & \multicolumn{4}{|c|}{ Air temperature $\left({ }^{\circ} \mathrm{C}\right)$} & \multirow{2}{*}{\multicolumn{2}{|c|}{$\begin{array}{l}\text { Relative } \\
\text { humidity } \\
(\%)\end{array}$}} & \multirow{2}{*}{\multicolumn{2}{|c|}{$\begin{array}{l}\text { Wind } \\
\text { speed } \\
\left(\mathrm{m} \mathrm{sec}^{-1}\right)\end{array}$}} & \multirow{3}{*}{$\begin{array}{l}\begin{array}{l}\text { Solar } \\
\text { radiation } \\
\left(\mathrm{MJ} \mathrm{m}^{-2}\right.\end{array} \\
\text { day-1) } \\
2019\end{array}$} & \multirow[b]{3}{*}{2020} & \multirow{2}{*}{\multicolumn{2}{|c|}{$\begin{array}{l}\mathrm{ET}_{\mathrm{o}} \\
\left(\mathrm{mm} \text { day }^{-1}\right)\end{array}$}} \\
\hline & \multicolumn{2}{|c|}{ Minimum } & \multicolumn{2}{|c|}{ Maximum } & & & & & & & & \\
\hline & 2019 & 2020 & 2019 & 2020 & 2019 & 2020 & 2019 & 2020 & & & 2019 & 2020 \\
\hline May & 17.31 & 17.06 & 31.42 & 30.34 & 46.09 & 49.72 & 3.40 & 3.63 & 27.52 & 27.58 & 3.83 & 3.74 \\
\hline June & 21.51 & 19.15 & 32.84 & 31.43 & 56.97 & 54.92 & 3.52 & 3.43 & 28.80 & 29.86 & 3.89 & 3.86 \\
\hline July & 23.06 & 21.80 & 34.17 & 33.45 & 55.90 & 58.84 & 3.49 & 3.52 & 29.42 & 29.48 & 3.90 & 3.91 \\
\hline August & 23.09 & 23.07 & 34.31 & 34.25 & 58.10 & 59.69 & 3.20 & 3.47 & 27.36 & 27.31 & 4.00 & 4.16 \\
\hline
\end{tabular}

Data obtained from Central Laboratory of Meteorology, Ministry of Agriculture and Land Reclamation, Egypt

Table 2 Calculated irrigation water amounts $\left(\mathrm{m}^{3} \mathrm{ha}^{-1}\right)$ based on irrigation levels of sunflower in 2019 and 2020 seasons

\begin{tabular}{|c|c|c|c|c|c|}
\hline \multicolumn{2}{|l|}{$\mathrm{WR}_{100 \%}$} & \multicolumn{2}{|l|}{$\mathrm{WR}_{85 \%}$} & \multicolumn{2}{|l|}{$\mathrm{WR}_{70 \%}$} \\
\hline 2019 & 2020 & 2019 & 2020 & 2019 & 2020 \\
\hline 5311.90 & 5226.19 & 4735.99 & 4650.79 & 4160.08 & 4075.38 \\
\hline
\end{tabular}

$W R_{100 \%}, W R_{85 \%}$, and $W R_{70 \%}$ applied irrigation water at 100, 85 and $70 \%$ of crop evapotranspiration, respectively

ane as organic solvent) and iodine value were determined as described by AOAC (2012).

\section{Crop Measurements}

At harvest dates (on $4^{\text {th }}$ and $10^{\text {th }}$ August in 2019 and 2020 seasons, respectively), whole plants of each plot were harvested to estimate head diameter, seed yield head ${ }^{-1}$, seed index, as well as seed yield $\mathrm{ha}^{-1}$.

\section{Water Use Efficiency (WUE)}

Based on the obtained seed yield and amount of applied irrigation water, WUE of sunflower was computed by Eq. 3, according to Jensen (1983) as follows:

WUE $=\frac{\text { Seed yield }}{\text { Applied irrigation water }}\left(\mathrm{kg} \mathrm{m}^{-3}\right)$

\section{Statistical Analysis}

Data for each growing season were subjected to two-way analysis of variance (ANOVA) according to Casella (2008), using Costat software program Version 6.303 (2004). For comparing among treatment means, Duncan's multiple range test at 0.05 probability level was used.

\section{Results}

\section{Physiological Traits}

Data in Table 3 revealed that each shortage in water supply, less than the normal (well-watered treatment, i.e. $\mathrm{WR}_{100 \%}$ ) caused lowering in total chlorophyll and carotenoids and increasing in free proline content. Moderate water-stressed $\left(\mathrm{WR}_{85} \%\right)$ and severe water-stressed $\left(\mathrm{WR}_{70 \%}\right)$ plants recorded decreases of 28.6 and $45.5 \%$ in total chlorophyll, 21.6 and $38.6 \%$ in carotenoids and increments of 119.6 and $295.2 \%$ in proline in comparison with $\mathrm{WR}_{100 \%}$, in the first season, respectively. The corresponding values obtained in the second season were 31.5 and $50.3 ; 32.8$ and $43.4 \%$, and 108.9 and $268.5 \%$, respectively.

Foliar spraying of salicylic acid (SA) (at 0.5 or $1.0 \mathrm{mM}$, i.e. $\mathrm{SA}_{0.5}$ and $\mathrm{SA}_{1.0}$, respectively) had simulative effect on total chlorophyll and carotenoids with inhibitive impact on proline content (Table 3). These contradictory effects were pronounced with each change in the applied SA concentration; the simulative effects of SA levels on chlorophyll and carotenoids were in the following order: $\mathrm{SA}_{1.0}>\mathrm{SA}_{0.5}>\mathrm{SA}_{0.0}$, while the opposite was the true as for proline content. $\mathrm{SA}_{1.0}$ treatment achieved the highest increases amounted to 27.4 and $32.4 \%$ in total chlorophyll and 23.9 and $26.3 \%$ in carotenoids over than $\mathrm{SA}_{0.0}$, in the first and second seasons, respectively. Meanwhile, the corresponding concomitant reductions in proline content were 18.1 and $17.9 \%$, respectively.

The adverse effects of drought stress on leaf contents of chlorophyll, carotenoids, and proline were markedly diminished and less obvious when sunflower plants were sprayed with SA. Under every irrigation level, total chlorophyll and carotenoids increased while proline content decreased with 
Table 3 Leaf chlorophyll, carotenoids, and proline contents of sunflower as affected by irrigation level, salicylic acid rate in 2019 and 2020 seasons

\begin{tabular}{|c|c|c|c|c|c|c|}
\hline \multirow[t]{2}{*}{ Treatment } & \multicolumn{2}{|c|}{ Carotenoids $\left(\mathrm{mg} \mathrm{g}^{-1}\right)$} & \multicolumn{2}{|c|}{ Chlorophyll $\left(\mathrm{mg} \mathrm{g}^{-1}\right)$} & \multicolumn{2}{|c|}{ Proline $\left(\mathrm{mg} \mathrm{g}^{-1}\right)$} \\
\hline & 2019 & 2020 & 2019 & 2020 & 2019 & 2020 \\
\hline \multicolumn{7}{|c|}{ Irrigation level, WR } \\
\hline $\mathrm{WR}_{100 \%}$ & $0.827 \mathrm{a}$ & $0.776 \mathrm{a}$ & $3.85 \mathrm{a}$ & $3.52 \mathrm{a}$ & $118.51 \mathrm{c}$ & $130.07 \mathrm{c}$ \\
\hline WR85\% & $0.648 \mathrm{~b}$ & $0.591 \mathrm{~b}$ & $2.75 \mathrm{~b}$ & $2.41 \mathrm{~b}$ & $260.22 \mathrm{~b}$ & $271.71 \mathrm{~b}$ \\
\hline $\mathrm{WR}_{70 \%}$ & $0.508 \mathrm{c}$ & $0.439 \mathrm{c}$ & $2.10 \mathrm{c}$ & $1.75 \mathrm{c}$ & $468.37 \mathrm{a}$ & $479.28 \mathrm{a}$ \\
\hline \multicolumn{7}{|c|}{ Salicylic acid rate, $S A$} \\
\hline $\mathrm{SA}_{0.0}$ & $0.578 \mathrm{c}$ & $0.520 \mathrm{c}$ & $2.48 \mathrm{c}$ & $2.13 \mathrm{c}$ & $316.35 \mathrm{a}$ & $328.18 \mathrm{a}$ \\
\hline $\mathrm{SA}_{0.5}$ & $0.687 \mathrm{~b}$ & $0.628 \mathrm{~b}$ & $3.07 \mathrm{~b}$ & $2.73 \mathrm{~b}$ & $271.71 \mathrm{~b}$ & $283.61 \mathrm{~b}$ \\
\hline $\mathrm{SA}_{1.0}$ & $0.716 \mathrm{a}$ & $0.657 \mathrm{a}$ & $3.16 \mathrm{a}$ & $2.82 \mathrm{a}$ & $259.05 \mathrm{c}$ & $269.28 \mathrm{c}$ \\
\hline \multicolumn{7}{|l|}{$W R \times S A$} \\
\hline $\mathrm{WR}_{100 \%} \times \mathrm{SA}_{0.0}$ & $0.723 \mathrm{c}$ & $0.672 \mathrm{c}$ & $3.24 \mathrm{c}$ & $2.91 \mathrm{c}$ & $139.85 \mathrm{~g}$ & $151.11 \mathrm{~g}$ \\
\hline $\mathrm{WR}_{100 \%} \times \mathrm{SA}_{0.5}$ & $0.868 \mathrm{~b}$ & $0.817 \mathrm{~b}$ & $4.12 \mathrm{~b}$ & $3.79 \mathrm{~b}$ & $111.65 \mathrm{~h}$ & $123.36 \mathrm{~h}$ \\
\hline $\mathrm{WR}_{100 \%} \times \mathrm{SA}_{1.0}$ & $0.889 \mathrm{a}$ & $0.838 \mathrm{a}$ & $4.19 \mathrm{a}$ & $3.86 \mathrm{a}$ & $104.04 \mathrm{i}$ & $115.75 \mathrm{~h}$ \\
\hline $\mathrm{WR}_{85 \%} \times \mathrm{SA}_{0.0}$ & $0.551 \mathrm{e}$ & $0.494 \mathrm{e}$ & $2.34 \mathrm{f}$ & $2.00 \mathrm{f}$ & $299.83 \mathrm{~d}$ & $312.11 \mathrm{~d}$ \\
\hline $\mathrm{WR}_{85} \% \times \mathrm{SA}_{0.5}$ & $0.680 \mathrm{~d}$ & $0.623 \mathrm{~d}$ & $2.90 \mathrm{e}$ & $2.56 \mathrm{e}$ & $249.80 \mathrm{e}$ & $260.83 \mathrm{e}$ \\
\hline $\mathrm{WR}_{85} \% \times \mathrm{SA}_{1.0}$ & $0.713 \mathrm{c}$ & $0.656 \mathrm{c}$ & $3.01 \mathrm{~d}$ & $2.67 \mathrm{~d}$ & $231.04 \mathrm{f}$ & $242.18 \mathrm{f}$ \\
\hline $\mathrm{WR}_{70 \%} \times \mathrm{SA}_{0.0}$ & $0.462 \mathrm{~g}$ & $0.393 \mathrm{~g}$ & $1.85 \mathrm{i}$ & $1.49 \mathrm{i}$ & $509.38 \mathrm{a}$ & $521.31 \mathrm{a}$ \\
\hline $\mathrm{WR}_{70 \%} \times \mathrm{SA}_{0.5}$ & $0.514 \mathrm{f}$ & $0.445 \mathrm{f}$ & $2.19 \mathrm{~h}$ & $1.83 \mathrm{~h}$ & $453.66 \mathrm{~b}$ & $466.62 \mathrm{~b}$ \\
\hline $\mathrm{WR}_{70 \%} \times \mathrm{SA}_{1.0}$ & $0.547 \mathrm{e}$ & $0.477 \mathrm{e}$ & $2.28 \mathrm{~g}$ & $1.92 \mathrm{~g}$ & $442.07 \mathrm{c}$ & $449.91 \mathrm{c}$ \\
\hline
\end{tabular}

Different letters within columns indicate that there are significant differences by Duncan's multiple range test at $p=0.05$

$W R_{100 \%}, W R_{85} \%$, and $W_{70 \%}$ applied irrigation water at 100, 85 and $70 \%$ of crop evapotranspiration, respectively, $S A_{0.0}, S A_{0.5}$, and $S A_{1.0}$ salicylic acid level at $0.0,0.5$, and $1 \mathrm{mM}$, respectively

the involvement of SA (Table 3). In this connection, treated plants with $\mathrm{WR}_{100 \%} \times \mathrm{SA}_{1.0}$ contained the highest amounts of total chlorophyll and carotenoids as well as the lowest proline content. Applying $\mathrm{WR}_{100 \%} \times \mathrm{SA}_{1.0}$ recorded increases of 126.5 and $159.1 \%$ in total chlorophyll and 92.4 and $113.2 \%$ in carotenoids over than those recorded with applying $\mathrm{WR}_{70 \%} \times \mathrm{SA}_{0.0}$, in the first and second seasons, respectively.

\section{Agronomic Traits}

Marked influence of the applied irrigation levels was exhibited on leaf area, head diameter, seed yield/head, seed index, and seed yield ha ${ }^{-1}$ of sunflower (Table 4). Each defect in the amount of irrigation water obviously decreased values of all agronomic traits. Therefore, the adverse effect was more severe when water supply lowered to $70 \%$ of ETc $\left(\mathrm{WR}_{70 \%}\right)$. Growing sunflower plants under diminishing water requirements of $15 \%$ or $30 \%$ (from $\mathrm{WR}_{100 \%}$ to $\mathrm{WR}_{85 \%}$ or to $\mathrm{WR}_{70 \%}$ ) showed seed yield reductions of 24.8 and $47.8 \%$ in 2019 season and 25.3 and $48.1 \%$ in the 2020 season, respectively.

Foliar application of SA improved all agronomic traits; the highest concentration was the most effective in each case (Table 4). Application either $\mathrm{SA}_{0.5 \%}$ or $\mathrm{SA}_{1.0}$ gained increases in seed yield by about 8.8 and $10.4 \%$ in the first season and 13.5 and $15.2 \%$ in the second one, respectively.
Concerning the interaction effect, the combinations of irrigation and salicylic acid levels varied significantly in affecting all agronomic traits (Table 4). Under all irrigation treatments, foliar spraying with SA improved seed yield; more beneficial effects were provided with increasing the applied SA concentration, almost in all cases. Sunflower plants treated by $\mathrm{WR}_{100 \%} \times \mathrm{SA}_{1.0}$, proved superiority over all investigated treatments except that of $\mathrm{WR}_{100 \%} \times \mathrm{SA}_{0.5}$ as for leaf area and seed yield $\mathrm{ha}^{-1}$ in the second season. The maximum seed yield was attained by applying $\mathrm{WR}_{100 \%} \times \mathrm{SA}_{1.0}$ (in both growing seasons) or $\mathrm{WR}_{100 \%} \times \mathrm{SA}_{0,5}$ (in the second season only). Seed yield of $\mathrm{WR}_{100 \%} \times \mathrm{SA}_{1.0}$ treatment was higher than that of $\mathrm{WR}_{70 \%} \times \mathrm{SA}_{0.0}$ by $109.7 \%$ in the first season and $125.9 \%$ in the second one. Additionally, as averages of the two seasons, reductions in seed yield due to lowering water supply by 15 and $30 \%$ were $21.0,15.8$ and $14.4 \%$ as well as $46.2,40.8$ and $40.1 \%$ with $\mathrm{SA}_{0.0}, \mathrm{SA}_{0.5}$ and $\mathrm{SA}_{1.0}$, respectively, compared to the farmer common practice $\left(\mathrm{WR}_{100 \%} \times \mathrm{SA}_{0.0}\right)$.

\section{Seed Oil Quality}

Sunflower seed oil percentage and iodine value were statistically influenced by the applied irrigation levels (Table 5). In this regard, data obviously revealed, in both seasons, enhancement effect of each addition of water supply up to the well-watered condition $\left(\mathrm{WR}_{100 \%}\right)$. Seeds of sunflower plants 
Table 4 Leaf area, head diameter, seed yield/head, seed index, and seed yield of sunflower as affected by as affected by irrigation level, salicylic acid rate in 2019 and 2020 seasons

\begin{tabular}{|c|c|c|c|c|c|c|c|c|c|c|}
\hline \multirow[t]{2}{*}{ Treatment } & \multicolumn{2}{|c|}{ Leaf area $\left(\mathrm{cm}^{2}\right)$} & \multicolumn{2}{|c|}{ Head diameter $(\mathrm{cm})$} & \multicolumn{2}{|c|}{ Seed weight head ${ }^{-1}(\mathrm{~g})$} & \multicolumn{2}{|c|}{ Seed index $(\mathrm{g})$} & \multicolumn{2}{|c|}{ Seed yield $\left(\mathrm{kg} \mathrm{ha}^{-1}\right)$} \\
\hline & 2019 & 2020 & 2019 & 2020 & 2019 & 2020 & 2019 & 2020 & 2019 & 2020 \\
\hline \multicolumn{11}{|c|}{$\overline{\text { Irrigation level, WR }}$} \\
\hline $\mathrm{WR}_{100 \%}$ & $611.6 \mathrm{a}$ & $596.6 \mathrm{a}$ & $21.0 \mathrm{a}$ & $19.9 \mathrm{a}$ & $40.2 \mathrm{a}$ & $38.4 \mathrm{a}$ & $7.63 \mathrm{a}$ & $6.65 \mathrm{a}$ & $3023.1 \mathrm{a}$ & $2880.2 \mathrm{a}$ \\
\hline WR $85 \%$ & $458.9 \mathrm{~b}$ & $445.5 \mathrm{~b}$ & $15.3 \mathrm{~b}$ & $14.2 \mathrm{~b}$ & $25.3 \mathrm{~b}$ & $23.4 \mathrm{~b}$ & $6.58 \mathrm{~b}$ & $5.61 \mathrm{~b}$ & $2273.6 \mathrm{~b}$ & $2150.2 \mathrm{~b}$ \\
\hline $\mathrm{WR}_{70 \%}$ & $353.4 \mathrm{c}$ & $342.1 \mathrm{c}$ & $12.6 \mathrm{c}$ & $11.5 \mathrm{c}$ & $18.0 \mathrm{c}$ & $15.9 \mathrm{c}$ & $5.60 \mathrm{c}$ & $4.63 \mathrm{c}$ & $1579.3 \mathrm{c}$ & $1495.6 \mathrm{c}$ \\
\hline \multicolumn{11}{|c|}{ Salicylic acid rate, SA } \\
\hline $\mathrm{SA}_{0.0}$ & $419.5 \mathrm{c}$ & $405.8 \mathrm{c}$ & $13.9 \mathrm{c}$ & $12.9 \mathrm{c}$ & $23.2 \mathrm{c}$ & $21.3 \mathrm{c}$ & $6.19 \mathrm{c}$ & $5.21 \mathrm{c}$ & $2154.2 \mathrm{c}$ & $1985.2 \mathrm{c}$ \\
\hline $\mathrm{SA}_{0.5}$ & $497.5 \mathrm{~b}$ & $485.3 \mathrm{~b}$ & $17.1 \mathrm{~b}$ & $15.9 \mathrm{~b}$ & $29.5 \mathrm{~b}$ & $27.3 \mathrm{~b}$ & $6.76 \mathrm{~b}$ & $5.78 \mathrm{~b}$ & $2343.3 \mathrm{~b}$ & $2254.0 \mathrm{~b}$ \\
\hline $\mathrm{SA}_{1.0}$ & $507.0 \mathrm{a}$ & $493.0 \mathrm{a}$ & $17.8 \mathrm{a}$ & $16.8 \mathrm{a}$ & $30.7 \mathrm{a}$ & $29.0 \mathrm{a}$ & $6.85 \mathrm{a}$ & $5.90 \mathrm{a}$ & $2378.5 \mathrm{a}$ & $2286.9 \mathrm{a}$ \\
\hline \multicolumn{11}{|l|}{$W R \times S A$} \\
\hline $\mathrm{WR}_{100 \%} \times \mathrm{SA}_{0.0}$ & $543.7 \mathrm{c}$ & $529.7 \mathrm{~b}$ & $17.5 \mathrm{c}$ & $16.3 \mathrm{c}$ & $32.8 \mathrm{c}$ & $30.8 \mathrm{c}$ & $7.08 \mathrm{c}$ & $6.07 \mathrm{c}$ & $2754.9 \mathrm{c}$ & $2578.7 \mathrm{~b}$ \\
\hline $\mathrm{WR}_{100 \%} \times \mathrm{SA}_{0.5}$ & $640.3 \mathrm{~b}$ & $627.7 \mathrm{a}$ & $22.3 \mathrm{~b}$ & $21.3 \mathrm{~b}$ & $42.9 \mathrm{~b}$ & $41.2 \mathrm{~b}$ & $7.85 \mathrm{~b}$ & $6.86 \mathrm{~b}$ & $3125.1 \mathrm{~b}$ & $3017.7 \mathrm{a}$ \\
\hline $\mathrm{WR}_{100 \%} \times \mathrm{SA}_{1.0}$ & $651.0 \mathrm{a}$ & $632.3 \mathrm{a}$ & $23.3 \mathrm{a}$ & $22.2 \mathrm{a}$ & $44.9 \mathrm{a}$ & $43.1 \mathrm{a}$ & $7.95 \mathrm{a}$ & $7.02 \mathrm{a}$ & $3189.1 \mathrm{a}$ & $3044.3 \mathrm{a}$ \\
\hline $\mathrm{WR}_{85 \%} \times \mathrm{SA}_{0.0}$ & $387.3 \mathrm{f}$ & $372.9 \mathrm{e}$ & $13.6 \mathrm{f}$ & $12.6 \mathrm{f}$ & $22.1 \mathrm{f}$ & $20.2 \mathrm{e}$ & $6.16 \mathrm{f}$ & $5.17 \mathrm{e}$ & $2186.9 \mathrm{e}$ & $2029.1 \mathrm{e}$ \\
\hline $\mathrm{WR}_{85 \%} \times \mathrm{SA}_{0.5}$ & $487.2 \mathrm{e}$ & $474.1 \mathrm{~d}$ & $15.8 \mathrm{e}$ & $14.4 \mathrm{e}$ & $26.3 \mathrm{e}$ & $24.3 \mathrm{~d}$ & $6.76 \mathrm{e}$ & $5.80 \mathrm{~d}$ & $2303.2 \mathrm{~d}$ & $2186.2 \mathrm{~d}$ \\
\hline $\mathrm{WR}_{85} \% \times \mathrm{SA}_{1.0}$ & $502.1 \mathrm{~d}$ & $489.5 \mathrm{c}$ & $16.6 \mathrm{~d}$ & $15.5 \mathrm{~d}$ & $27.4 \mathrm{~d}$ & $25.7 \mathrm{~d}$ & $6.83 \mathrm{~d}$ & $5.86 \mathrm{~d}$ & $2330.6 \mathrm{~d}$ & $2235.4 \mathrm{c}$ \\
\hline $\mathrm{WR}_{70} \% \times \mathrm{SA}_{0.0}$ & $327.6 \mathrm{~h}$ & $315.0 \mathrm{~g}$ & $10.7 \mathrm{~g}$ & $9.6 \mathrm{~g}$ & $14.7 \mathrm{~h}$ & $13.0 \mathrm{~h}$ & $5.35 \mathrm{i}$ & $4.39 \mathrm{~h}$ & $1520.7 \mathrm{~g}$ & $1347.8 \mathrm{~g}$ \\
\hline $\mathrm{WR}_{70 \%} \times \mathrm{SA}_{0.5}$ & $364.9 \mathrm{~g}$ & $354.2 \mathrm{f}$ & $13.3 \mathrm{f}$ & $12.2 \mathrm{f}$ & $19.3 \mathrm{~g}$ & $16.5 \mathrm{~g}$ & $5.67 \mathrm{~h}$ & $4.70 \mathrm{~g}$ & $1601.5 \mathrm{f}$ & $1558.2 \mathrm{f}$ \\
\hline $\mathrm{WR}_{70 \%} \times \mathrm{SA}_{1.0}$ & $367.7 \mathrm{~g}$ & $357.0 \mathrm{f}$ & $13.7 \mathrm{f}$ & $12.7 \mathrm{f}$ & $19.9 \mathrm{~g}$ & $18.3 \mathrm{f}$ & $5.77 \mathrm{~g}$ & $4.81 \mathrm{f}$ & $1615.7 \mathrm{f}$ & $1580.9 \mathrm{f}$ \\
\hline
\end{tabular}

Different letters within columns indicate that there are significant differences by Duncan's multiple range test at $p=0.05$

$W R_{100 \%}, W R_{85 \%}$, and $W_{70 \%}$ applied irrigation water at 100, 85 and 70\% of crop evapotranspiration, respectively, $S A_{0.0}, S A_{0.5}$, and $S A_{1.0}$ salicylic acid level at $0.0,0.5$, and $1 \mathrm{mM}$, respectively

Table 5 Seed oil percentage and iodine value of sunflower as affected by as affected by irrigation level, salicylic acid rate in 2019 and 2020 seasons

\begin{tabular}{|c|c|c|c|c|}
\hline \multirow[t]{2}{*}{ Treatment } & \multicolumn{2}{|l|}{ Oil \% } & \multicolumn{2}{|c|}{ Iodine value } \\
\hline & 2019 & 2020 & 2019 & 2020 \\
\hline \multicolumn{5}{|c|}{ Irrigation level, WR } \\
\hline $\mathrm{WR}_{100 \%}$ & $38.18 \mathrm{a}$ & $37.02 \mathrm{a}$ & $131.92 \mathrm{a}$ & $130.14 \mathrm{a}$ \\
\hline WR85\% & $34.92 \mathrm{~b}$ & $33.76 \mathrm{~b}$ & $124.37 \mathrm{~b}$ & $122.72 \mathrm{~b}$ \\
\hline $\mathrm{WR}_{70 \%}$ & $31.46 \mathrm{c}$ & $30.32 \mathrm{c}$ & $117.82 \mathrm{c}$ & $116.19 \mathrm{c}$ \\
\hline \multicolumn{5}{|c|}{ Salicylic acid rate, $S A$} \\
\hline $\mathrm{SA}_{0.0}$ & $33.35 \mathrm{c}$ & $32.13 \mathrm{c}$ & $121.59 \mathrm{c}$ & $119.87 \mathrm{c}$ \\
\hline $\mathrm{SA}_{0.5}$ & $35.51 \mathrm{~b}$ & $34.36 \mathrm{~b}$ & $125.89 \mathrm{~b}$ & $124.24 \mathrm{~b}$ \\
\hline $\mathrm{SA}_{1.0}$ & $35.70 \mathrm{a}$ & $34.61 \mathrm{a}$ & $126.62 \mathrm{a}$ & $124.93 \mathrm{a}$ \\
\hline \multicolumn{5}{|l|}{$W R \times S A$} \\
\hline $\mathrm{WR}_{100 \%} \times \mathrm{SA}_{0.0}$ & $36.91 \mathrm{~b}$ & $35.73 \mathrm{~b}$ & $129.98 \mathrm{c}$ & $128.08 \mathrm{c}$ \\
\hline $\mathrm{WR}_{100 \%} \times \mathrm{SA}_{0.5}$ & $38.75 \mathrm{a}$ & $37.58 \mathrm{a}$ & $132.57 \mathrm{~b}$ & $130.85 \mathrm{~b}$ \\
\hline $\mathrm{WR}_{100 \%} \times \mathrm{SA}_{1.0}$ & $38.87 \mathrm{a}$ & $37.75 \mathrm{a}$ & $133.20 \mathrm{a}$ & $131.49 \mathrm{a}$ \\
\hline $\mathrm{WR}_{85} \% \times \mathrm{SA}_{0.0}$ & $33.42 \mathrm{~d}$ & $32.17 \mathrm{~d}$ & $121.41 \mathrm{f}$ & $119.79 \mathrm{f}$ \\
\hline $\mathrm{WR}_{85 \%} \times \mathrm{SA}_{0.5}$ & $35.62 \mathrm{c}$ & $34.53 \mathrm{c}$ & $125.37 \mathrm{e}$ & $123.71 \mathrm{e}$ \\
\hline $\mathrm{WR}_{85 \%} \times \mathrm{SA}_{1.0}$ & $35.72 \mathrm{c}$ & $34.59 \mathrm{c}$ & $126.31 \mathrm{~d}$ & $124.66 \mathrm{~d}$ \\
\hline $\mathrm{WR}_{70 \%} \times \mathrm{SA}_{0.0}$ & $29.71 \mathrm{~g}$ & $28.49 \mathrm{~g}$ & $113.38 \mathrm{i}$ & $111.73 \mathrm{i}$ \\
\hline $\mathrm{WR}_{70 \%} \times \mathrm{SA}_{0.5}$ & $32.16 \mathrm{f}$ & $30.98 \mathrm{f}$ & $119.74 \mathrm{~h}$ & $118.18 \mathrm{~h}$ \\
\hline $\mathrm{WR}_{70 \%} \times \mathrm{SA}_{1.0}$ & $32.53 \mathrm{e}$ & $31.49 \mathrm{e}$ & $120.34 \mathrm{~g}$ & $118.65 \mathrm{~g}$ \\
\hline
\end{tabular}

Different letters within columns indicate that there are significant differences by Duncan's multiple range test at $p=0.05$

$W R_{100 \%}, W R_{85} \%$, and $W_{70 \%}$ applied irrigation water at 100, 85 and $70 \%$ of crop evapotranspiration, respectively, $S A_{0.0}, S A_{0.5}$, and $S A_{1.0}$ salicylic acid level at $0.0,0.5$, and $1 \mathrm{mM}$, respectively 
grown under water requirement reduction of $15 \%$ or $30 \%$ (from $\mathrm{WR}_{100 \%}$ to $\mathrm{WR}_{85 \%}$ or to $\mathrm{WR}_{70 \%}$ ) had 8.5 and $17.6 \%$ less in seed oil\% and 5.7 and $10.7 \%$ less in iodine value in 2019 season, respectively, comparing well-watered plants. The corresponding reductions in the 2020 season were 8.8 and $18.1 \%$ for seed oil $\%$ and 5.7 and $10.7 \%$ for iodine value, respectively. On the other hand, it could be obviously noted that foliar application of SA improved seed oil percentage and iodine value as well. The advantages of SA achieved in seed oil percentage and iodine value were almost more with $\mathrm{SA}_{1.0}$. In both seasons, $\mathrm{WR}_{100 \%} \times \mathrm{SA}_{1.0}$ for iodine value as well as $\mathrm{WR}_{100 \%} \times \mathrm{SA}_{1.0}$ and $\mathrm{WR}_{100 \%} \times \mathrm{SA}_{0.5}$ for seed oil $\%$ recorded the highest. Data clearly illustrated that implicating SA spray, in the applied combination treatments, had beneficial effects on seed oil $\%$ and iodine value. Meanwhile, the lowest values of both traits were detected in oil of seeds produced by plants grown under severely water-stress condition without receiving $\mathrm{SA}\left(\mathrm{WR}_{70 \%} \times \mathrm{SA}_{0.0}\right)$.

\section{Water Use Efficiency}

As depicted in Figs. 1 and 2, the more the irrigation amount and SA rate increase, the more the WUE increases. Accordingly, the increases in WUE due to $\mathrm{WR}_{100 \%}$ and $\mathrm{WR}_{85 \%}$ were 49.9 and $26.5 \%$ in the first season and 50.2 and $26.0 \%$ in the second one, respectively compared to $\mathrm{WR}_{70 \%}$ (Fig. 1). Also, WUE showed increases of 10.0 and $8.4 \%$ as well as 15.1 and $13.4 \%$ with application of $\mathrm{SA}_{1.0}$ and $\mathrm{SA}_{0.5}$ in the first and second season, respectively, compared to $\mathrm{SA}_{0.0}$ (Fig. 2).

The beneficial effect of SA implication on WUE was pronounced under well-watered condition, in both seasons. The differences in WUE between $\mathrm{WR}_{100 \%} \times \mathrm{SA}_{1.0}$ and $\mathrm{WR}_{100 \%} \times \mathrm{SA}_{0.5}$ didn't reach the $\mathrm{P}<0.05$ level of significance in 2020 season, with the superiority of $\mathrm{WR}_{100 \%} \times \mathrm{SA}_{1.0}$

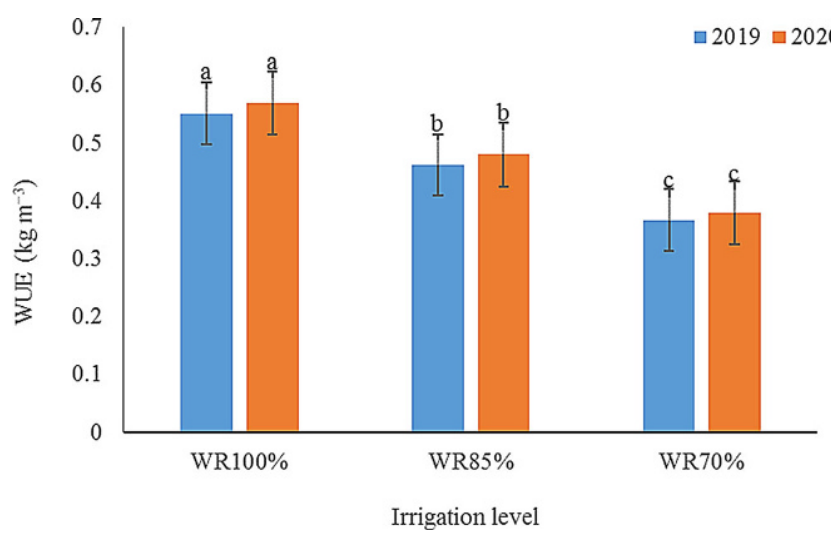

Fig. 1 Water use efficiency (WUE) of sunflower as affected by irrigation level in 2019 and 2020 seasons. (Different letters of the bars indicate that there are significant differences by Duncan's multiple range test at $p=0.05$. WR $100 \%$, WR $85 \%$, and WR70\% applied irrigation water at 100,85 and $70 \%$ of crop evapotranspiration, respectively)

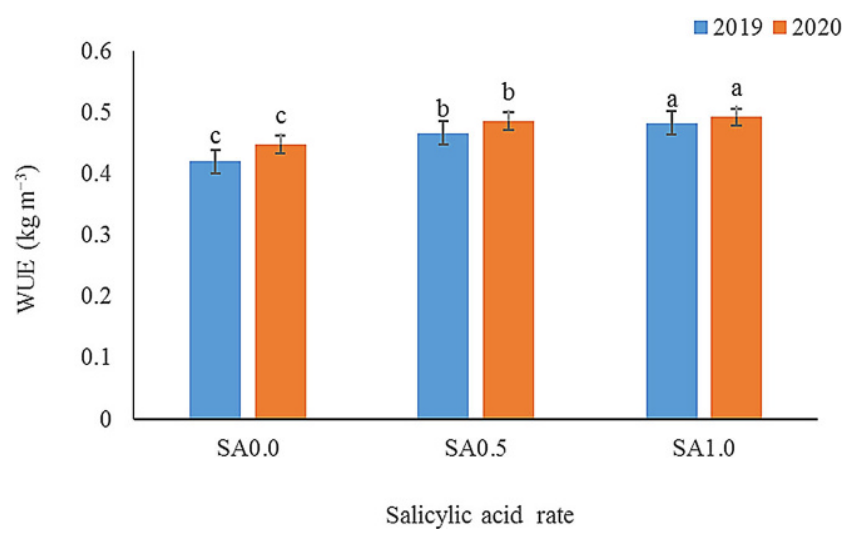

Fig. 2 Water use efficiency (WUE) of sunflower as affected by salicylic acid rate in 2019 and 2020 seasons. (Different letters of the bars indicate that there are significant differences by Duncan's multiple range test at $p=0.05$. SA0.0, SA0.5, and SA1.0 salicylic acid level at $0.0,0.5$, and $1 \mathrm{mM}$, respectively)

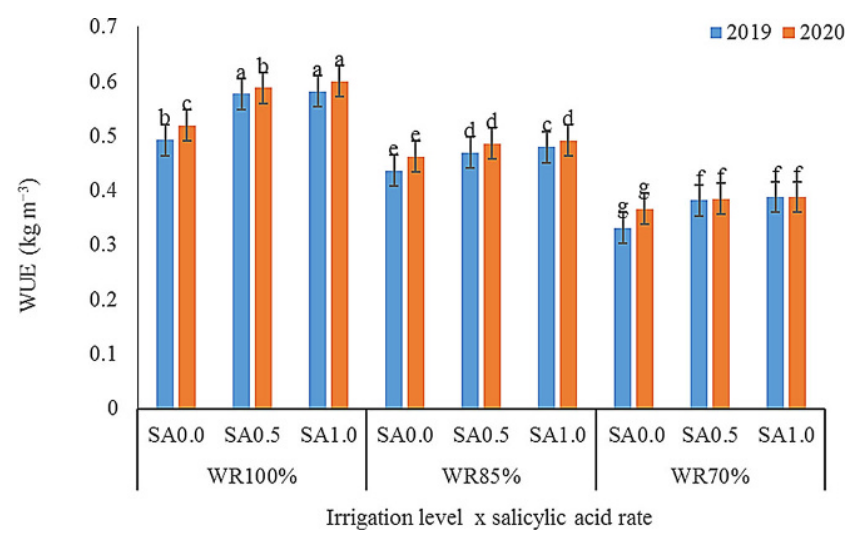

Fig. 3 Water use efficiency (WUE) of sunflower as affected by the interaction of irrigation level and salicylic acid rate in 2019 and 2020 seasons. (Different letters of the bars indicate that there are significant differences by Duncan's multiple range test at $p=0.05$. WR $100 \%$, WR $85 \%$, and WR70\% applied irrigation water at 100, 85 and $70 \%$ of crop evapotranspiration, respectively, SA0.0, SA0.5, and SA1.0 salicylic acid level at $0.0,0.5$, and $1 \mathrm{mM}$, respectively)

in 2019 season. On the contrary, severely water-stressed plants without receiving foliar SA $\left(\mathrm{WR}_{70 \%} \times \mathrm{SA}_{0.0}\right)$ recorded the lowest WUE (Fig. 3).

\section{Discussion}

Since drought causes changes in molecular, biochemical, physiological, and morphological aspects resulting in negative effects on plant growth and development (Nam et al. 2020; Taha et al. 2020; Babaei et al. 2021; El-Metwally and Saudy 2021; El-Metwally et al. 2021; Salem et al. 2022), injurious impacts of water deficit on different sunflower traits were occurred (Table 3, 4 and 5). The present study confirmed the negative impact of water deficit/on 
plant physiological status. Owing to the relationship between the plant biochemical compounds and deficit water, drought stress led to degradation of photosynthesis pigments (chlorophylls and carotenoids), as well as accumulation of proline (Table 3). Such findings are in accordance with those recorded by Manivannan et al. (2007) and Saudy et al. (2021) who reported that subjecting sunflower plants to water deficit caused decreases in total chlorophyll and carotenoids and increases proline content in leaves. During drought, reactive oxygen species (ROS) accumulate, which are toxic at elevated levels, due to reduced electron transport chain activity (Hasanuzzaman et al. 2020). Overproduction of ROS is concomitant to various abiotic stresses (Gill and Tuteja 2010; Hossain et al. 2014; Souri et al. 2019; Hatamian et al. 2020). ROS react with and deteriorate nucleic acids (DNA), proteins, photosynthetic pigments, and membrane lipids (Zulfiqar and Ashraf 2021). Elevated ROS levels lead to inactivation of proteins and inhibit the activity of multiple enzymes involved in metabolic pathways, and result in oxidation of lipids and DNA (Hossain et al. 2014). Consequently, ROS can damage membrane and other essential macromolecules (such as photosynthetic pigments, proteins, DNA and lipids), so reducing contents of chlorophylls and carotenoides as shown under drought stress (Table 3). However, plants have natural defense systems involving non-enzymatic and enzymatic antioxidants that efficiently ameliorate the negative impacts of excessive ROS (Zulfiqar and Ashraf 2021). Moreover, plants acclimate to ROS-induced stress by producing various beneficial compatible solutes, such as proline and glycine betaine (Shemi et al. 2021). Subjecting sunflower plants to drought stress increases proline content while reduced the activity of proline oxidase in leaves (Manivannan et al. 2007). Content of chlorophyll, which is one of the major chloroplast components for photosynthesis, has a positive relationship with photosynthetic rate (Anjum et al. 2011). Degradation in photosynthetic pigments can directly limit photosynthetic potential which adversely affects plant productivity. The decrease in chlorophyll content under drought stress may be the result of pigment photo-oxidation and chlorophyll degradation. Photosynthetic pigments of plants are important for harvesting light and production of reducing powers (Anjum et al. 2011). Accordingly, marked reductions were exhibited in leaf area, head diameter, seed yield/head, seed index, seed yield $\mathrm{ha}^{-1}$, seed oil content and iodine value (Table 4) as well as water use efficiency (Fig. 1) of sunflower subjected to drought stress. Many researchers have reported decreasing performance of sunflower growth under water stress conditions (Erdem et al. 2006; Nezami et al. 2008). Water deficit reduces sunflower yield and quality (El-Bially et al. 2018; El-Metwally et al. 2022). Following drought, stomata close progressively with a parallel decline in net photosynthesis and water-use efficiency (Anjum et al. 2011). The closure of stomata significantly decreases the photosynthetic and transpiration rate (Jaleel et al. 2007) and negatively influences the crop growth and productivity (Du et al. 2010). Drought stress significantly decreased all the photosynthetic parameters, i.e. net photosynthetic rate, stomatal conductance, internal carbon dioxide concentration, as well as water use efficiency (WUE) and transpiration rate (Hayat et al. 2008). The lack of photosynthetic pigment contents in the leaves (Table 3), under stresses, leads to a decrease in the efficiency of photosynthesis, which in turn affects the productivity and decrease seeds oil content of sunflower plants (Saudy et al. 2021). Moreover, the harmful effect of drought could be attributed to reduce the availability of nutrients in soil with disturbance in plant nutritional status associated low water supply (Saudy and El-Metwally 2019; Mubarak et al. 2021; Salem et al. 2021; Abd-Elrahman et al. 2022).

Not only SA had a beneficial effect on plant growth and development under water stress conditions but also under normal water supply. In this respect, SA is one of the main plant growth regulators that play a vital role in controlling and modulating photosynthesis under both normal and stressful condition (Arif et al. 2020). SA has key role in enhancing photosynthesis by upregulating photosynthetic enzyme and carbohydrate metabolism (Khodary 2004). SA application increased photosynthetic activity, chlorophyll content, and enzyme activity under both normal and stress conditions ( $\mathrm{Li}$ et al. 2014). Therefore, total chlorophyll and carotenoids increased while proline content decreased with SA supply under every irrigation level (Table 3). Such findings may be reflected and interpreted, partially at least, the enhancements achieved in sunflower growth and productivity due to exogenous application of SA. The enhancement in sunflower growth with application of SA could be attributed to the role of SA in maintenance the photosynthetic machinery and activity, then promoting the plant growth. SA, which is a plant hormone (Davies 2010) is a multifaceted plant growth regulator which participates in a wide range of growth, metabolism and defense systems; it acts a typical plant hormone modulating all plant responses and providing plant immunity against various stresses (Arif et al. 2020). SA enhances various physiological processes like photosynthesis, chlorophyll and other pigment, plant growth and development, and flowering (Arif et al. 2020). SA plays a key role in providing tolerance to the plants exposed to water stress, i.e. drought or flooding (Hayat et al. 2010). Exogenous application of SA facilitates growth; and flowering; up-regulates photosynthesis; increases the activity of enzymatic and non-enzymatic antioxidants (Arif et al. 2020). Additionally, the generation of ROS during drought stress requires up-regulation of detoxification systems such as super oxide dismutase (SOD) and catalase enzymes and biosynthesis of ROS scavengers (You and Chan 
2015). Herein, SA enhances the activities of antioxidants enzyme system i.e. ascorbate peroxidase (APX) and superoxide dismutase (SOD) with a concomitant decline in the activity of catalase (CAT), and can protect and enhance the enzymes of nitrate metabolism under stressful environments (reviewed by Hayat et al. 2010). Also, SA enhances the activity of ROS scavenger enzymes, participates in eliciting abiotic stress responses such as drought (Arif et al. 2020), Application of SA in drought-stressed plants resulted in growth recovery, increased photosynthesis, and reduced oxidative stress (Zulfiqar et al. 2021). Therefore, foliar application of SA improved leaf area, head diameter, seed yield/head, seed index, seed yield ha ${ }^{-1}$ (Table 4), oil seed content and iodine value (Table 5) as well as WUE (Fig. 2) of sunflower. Also, WUE increases with alleviating water stress by applying SA (Fig. 3). Thus, the maximal values of WUE were recorded with $\mathrm{WR}_{100 \%} \times \mathrm{SA}_{1.0}$, followed by that of $\mathrm{WR}_{100 \%} \times \mathrm{SA}_{0.5}$. These findings could be owing to producing seed yields under such conditions more than under other ones, resulting in higher WUE values. At low WUE, photosynthetic carbon assimilation is decreased due to decreasing flow of $\mathrm{CO}_{2}$ into mesophyll tissue and the closure of stomata (Chaves et al. 2003; Flexas et al. 2004). Following drought, stomata close progressively with a parallel decline in net photosynthesis and WUE (Anjum et al. 2011). Moreover, different concentrations of SA increased total leaf chlorophyll content, photosynthesis and stomatal conductance under normal and stress conditions (Bastam et al. 2012; Ghasemzadeh and Jaafar 2013). SA stimulated $\mathrm{CO}_{2}$ fixation and efficiency of photosynthetic quantum (Poór et al. 2011). SA also helped to ignite photosynthetic process by closing stomata and by suppressing or slowing electron transport metabolism of PSII (Janda et al. 2012). Photosynthesis, stomatal conductance, gaseous exchange, $\mathrm{CO}_{2}$ assimilation rate, and chlorophyll content were enhanced after applying SA (Babar et al. 2014). SA elevated photosynthetic rate by facilitating carboxylation rate, chlorophyll amount that is SPAD values and by increasing turgor (Tahjib-Ul-Arif et al. 2018). Additionally, SA increased the chlorophyll, carotenoid, nitrogen, potassium and phosphorus level and nitrate reductase activity (Hashmi et al. 2012). It also maintains membrane integrity of chloroplast membrane (Huang et al. 2016).

\section{Conclusions}

It is interesting to conclude that salicylic acid has a substantial role for ameliorating growth and yield of sunflower. Such effect was more pronounced under water deficit, where salicylic acid partially alleviated the detrimental impact of low irrigation level. The current study proved that salicylic acid could be regarded as an inducer for drought tolerance. In this respect, compared to the farmer common practice $\left(\mathrm{WR}_{100 \%} \times \mathrm{SA}_{0.0}\right), \mathrm{SA}_{0.5}$ and $\mathrm{SA}_{1.0}$ alleviated the yield losses from $21.0 \%$ to 15.8 and $14.4 \%$ as well as $46.2 \%$ to 40.8 and $40.1 \%$ under lowering water supply by 15 and 30\%, respectively. The global climatic changes and water scarcity, as in arid and semi-arid regions, often obligate farmers to irrigate the crops using water amounts less than required or optimum. This means subjecting crop plants to drought stress, leading to yield losses. Therefore, inserting the plant growth regulator salicylic acid as a save and cheap practice in drought-imposed sunflower cultivation has become important to relatively alleviate the associated deleterious of water deficit.

Acknowledgements The authors acknowledge the technical support provided by Faculty of Agriculture, Ain Shams University and Central Laboratory for Agricultural Climate, Agricultural Research Center, Egypt.

Funding Open access funding provided by The Science, Technology \& Innovation Funding Authority (STDF) in cooperation with The Egyptian Knowledge Bank (EKB).

Conflict of interest M.E. El-Bially, H.S. Saudy, F.A. Hashem, Y.A. El-Gabry and M.G. Shahin declare that they have no competing interests.

Open Access This article is licensed under a Creative Commons Attribution 4.0 International License, which permits use, sharing, adaptation, distribution and reproduction in any medium or format, as long as you give appropriate credit to the original author(s) and the source, provide a link to the Creative Commons licence, and indicate if changes were made. The images or other third party material in this article are included in the article's Creative Commons licence, unless indicated otherwise in a credit line to the material. If material is not included in the article's Creative Commons licence and your intended use is not permitted by statutory regulation or exceeds the permitted use, you will need to obtain permission directly from the copyright holder. To view a copy of this licence, visit http://creativecommons.org/licenses/by/4. $0 /$.

\section{References}

Abbaszadeh B, Layeghhaghighi M, Azimi R, Hadi N (2020) Improving water use efficiency through drought stress and using salicylic acid for proper production of Rosmarinus officinalis L. Ind Crop Prod 144:111893

Abd-Elrahman SH, Saudy HS, Abd El-Fattah DA, Hashem FA (2022) Effect of irrigation water and organic fertilizer on reducing nitrate accumulation and boosting lettuce productivity. J Soil Sci Plant Nutr. https://doi.org/10.1007/s42729-022-00799-8

Abdelaal KAA (2015) Effect of Salicylic acid and Abscisic acid on morpho-physiological and anatomical characters of faba bean plants (Vicia faba L.) under drought stress. J Plant Prod Mansoura Univ 6:1771-1788

Ahmadi M, Souri MK (2018) Growth and mineral elements of coriander (Corianderum sativum L) plants under mild salinity with different salts. Acta Physiol Plant 40:94-99

Anderson R, Baye P, Edwards D (2020) Climate change and the need for agricultural adaptation. Curr Opin Plant Biol 56:197-202 
Anjum SA, Xie X, Wang L, Saleem MF, Man C, Lei W (2011) Morphological, physiological and biochemical responses of plants to drought stress. Afr J Agric Res 6:2026-2032

AOAC (2012) Official method of analysis: Association of Analytical Chemists, 19th edn. AOAC, Washington DC

Arif Y, Sami F, Siddiqui H, Bajguz A, Hayat S (2020) Salicylic acid in relation to other phytohormones in plant: A study towards physiology and signal transduction under challenging environment. Environ Exp Bot 175:104040. https://doi.org/10.1016/j.envexpbot. 2020.104040

Arnon DI (1949) Copper enzyme polyphenoloxides in isolated chloroplast in Beta vulgaris. Plant Physiol 24:1-15

Babaei K, Moghaddam M, Farhadi N, Pirbalouti AG (2021) Morphological, physiological and phytochemical responses of Mexican marigold (Tagetes minuta L.) to drought stress. Sci Hortic 284:110116

Babar S, Siddiqi EH, Hussain I, Hayat Bhatti K, Rasheed R (2014) Mitigating the effects of salinity by foliar application of salicylic acid in fenugreek. Physiol J. https://doi.org/10.1155/2014/ 869058.2014

Bastam N, Baninasab B, Ghobadi C (2012) Improving salt tolerance by exogenous application of salicylic acid in seedlings of pistachio. Plant Growth Regul 69:275-284. https://doi.org/10.1007/s10725012-9770-7

Bates LS, Waldren RP, Teare ID (1973) Rapid determination of free proline for water-stress studies. Plant Soil 39:205-207

Beadle CL (1993) Growth analysis. In: Hall DO (ed) Photosynthesis and production in a changing environment a field and laboratory manual. Chapman and Hall, London, pp 36-46

Casella G (2008) Statistical design, 1st edn. Springer, Gainesville, pp 32611-32545

Chaves MM, Maroco JP, Pereira J (2003) Understanding plant responses to drought - from genes to the whole plant. Funct Plant Biol 30:239-264

Chavoushi M, Najafi F, Salimi A, Angaji S (2019) Improvement in drought stress tolerance of safflower during vegetative growth by exogenous application of salicylic acid and sodium nitroprusside. Ind Crop Prod 134:168-176

Davies PJ (2010) The plant hormones: Their nature, occurrence, and functions. In: Davies PJ (ed) Plant hormones: biosynthesis, signal transduction, action!, 3rd edn. Springer, Dordrecht, pp 1-12

Doorenbos J, Pruitt WO (1977) Crop water requirements: irrigation and drainage. FAO paper, vol 24. FAO, Rome

Du NW, Zhang GX, Wang R (2010) Morphological and physiological responses of Vitex negundo L var heterophylla (Franch) Rehdto drought stress. Acta Physiol Plant 32:839-848

El-Bially MA, Saudy HS, El-Metwally IM, Shahin MG (2018) Efficacy of ascorbic acid as a cofactor for alleviating water deficit impacts and enhancing sunflower yield and irrigation water-use efficiency. Agric Water Manag 208:132-139

El-Bially MA, Saudy HS, El-Metwally IM, Shahin MG (2022) Sunflower response to application of $\mathrm{L}$-ascorbate under thermal stress associated different sowing dates. Gesunde Pflanz 74:87-96. https://doi.org/10.1007/s10343-021-00590-2

El-Metwally IM, Saudy HS (2021) Interactional impacts of drought and weed stresses on nutritional status of seeds and water use efficiency of peanut plants grown in arid conditions. Gesunde Pflanz 73:407-416. https://doi.org/10.1007/s10343-021-00557-3

El-Metwally IM, Geries L, Saudy HS (2022) Interactive effect of soil mulching and irrigation regime on yield, irrigation water use efficiency and weeds of trickle-irrigated onion. Arch Agron Soil Sci. https://doi.org/10.1080/03650340.2020.1869723

El-Metwally IM, Saudy HS, Abdelhamid MT (2021) Efficacy of benzyladenine for compensating the reduction in soybean productivity under low water supply. Ital J Agrometeorol 2:81-90

Erdem T, Swait J, Valenzuela A (2006) Brands as signals: a crosscountry validation study. J Mark 70:34-49
Farooq M, Hussain M, Wahid A, Siddique KHM (2012) Drought stress in plants In. In: Aroca R (ed) Plant responses to drought stress. Springer, Berlin, Heidelberg, pp 1-33

Flexas J, Bota J, Loreta F, Cornic G, Sharkey TD (2004) Diffusive and metabolic limitation to photosynthesis under drought and salinity in C3 plants. Plant Biol 6:269-279

Garcia-Vila M, Fereres E (2012) Herbaceous crops: Sunflower. In: Steduto P, Hsiao TC, Fereres E, Raes D (eds) Crop yield response to water. Irrigation and Drainage Paper, vol 66. FAO, Rome, pp 164-170

Ghasemzadeh A, Jaafar H (2013) Interactive effect of salicylic acid on some physiological features and antioxidant enzymes activity in ginger (Zingiber officinale Roscoe). Molecules 18:5965-5979. https://doi.org/10.3390/molecules 18055965

Gill SS, Tuteja N (2010) Reactive oxygen species and antioxidant machinery in abiotic stress tolerance in crop plants. Plant Physiol Biochem 48:909-930

Hasanuzzaman M, Bhuyan MB, Zulfiqar F, Raza A, Mohsin SM, Al Mahmud J, Fujita M, Fotopoulos V (2020) Reactive oxygen species and antioxidant defense in plants under abiotic stress: Revisiting the crucial role of a universal defense regulator. Antioxidants 9:681

Hashmi N, Khan MMA, Moinuddin Idrees M, Aftab T (2012) Exogenous salicylic acid stimulates physiological and biochemical changes to improve growth, yield and active constituents of fennel essential oil. Plant Growth Regul 68:281-291. https://doi.org/10.1007/s10725-012-9716-0

Hatamian M, Nejad RA, Kafi M, Souri MK, Shahbazi K (2020) Nitrate improves hackberry seedling growth under cadmium application. Heliyon 6:e3247

Hayat Q, Hayat S, Irfan M, Ahmad A (2010) Effect of exogenous salicylic acid under changing environment: A review. Environ Exp Bot 68:14-25

Hayat S, Hasan SA, Fariduddin Q, Ahmad A (2008) Growth of tomato (Lycopersicon esculentum) in response to salicylic acid under water stress. J Plant Int 3:297-304

Hossain MA, Hoque MA, Burritt DJ, Fujita M (2014) Proline protects plants against abiotic oxidative stress: biochemical and molecular mechanisms. In: Ahmad P (ed) Oxidative damage to plants: antioxidant networks and signaling. Academic Press, Elsevier, Amsterdam, pp 477-522

Huang C, Wang D, Sun L, Wei L (2016) Effects of exogenous salicylic acid on the physiological characteristics of Dendrobium officinale under chilling stress. Plant Growth Regul 79:199-208. https://doi.org/10.1007/s10725-015-0125-Z

IUSS Working Group WRB (2015) World reference base for soil resources 2014, update 2015 international soil classification system for naming soils and creating legends for soil maps. World soil resources reports, vol 106. FAO, Rome

Jaleel CA, Manivannan P, Sankar B, Kishorekumar A, Gopi R, Somasundaram R, Panneerselvam R (2007) Water deficit stress mitigation by calcium chloride in Catharanthus roseus, effects on oxidative stress, proline metabolism and indole alkaloid accumulation. Colloids Surf B Biointerfac 60:110-116

Janda K, Hideg É, Szalai G, Kovács L, Janda T (2012) Salicylic acid may indirectly influence the photosynthetic electron transport. J Plant Physiol 169:971-978. https://doi.org/10.1016/j.jplph. 2012.02.020

Jensen ME (1983) Design and operation of farm irrigation systems. ASAE, St. Joseph, p 827

Kang G, Li G, Liu G, Xu W, Peng X, Wang C, Zhu Y, Guo T (2013) Exogenous salicylic acid enhances wheat drought tolerance by influence on the expression of genes related to ascorbate-glutathione cycle. Biol Plant 57:718-724

Khan MIR, Asgher M, Khan NA (2014) Alleviation of salt-induced photosynthesis and growth inhibition by salicylic acid involves glycinebetaine and ethylene in mungbean (Vigna radiata L.). Plant Physiol Biochem 80:67-74 
Khodary SEA (2004) Effect of salicylic acid on the growth, photosynthesis and carbohydrate metabolism in salt stressed maize plants. Int J Agric Biol 6:5-8

La VH, Lee BR, Islam MT, Park SH, Jung HI, Bae DW, Kim TH (2019) Characterization of salicylic acid-mediated modulation of the drought stress responses: Reactive oxygen species, proline, and redox state in Brassica napus. Environ Exp Bot 157:1-10

Li T, Hu Y, Du X, Tang H, Shen C, Wu J (2014) Salicylic acid alleviates the adverse effects of salt stress in Torreya grandis cv. merrillii seedlings by activating photosynthesis and enhancing antioxidant systems. PLoS One 9:e109492. https://doi.org/10.1371/ journal.pone. 0109492

Makhlouf BSI, Khalil SRAE, Saudy HS (2022) Efficacy of humic acids and chitosan for enhancing yield and sugar quality of sugar beet under moderate and severe drought. J Soil Sci Plant Nutr. https://doi.org/10.1007/s42729-022-00762-7

Manivannan P, Jaleel CA, Sankar B, Kishorekumar A, Somasundaram R, Alagu Lakshmanan GM, Panneerselvam R (2007) Growth, biochemical modifications and proline metabolism in Helianthus annuus L. as induced by drought stress. Colloids Surf B Biointerfac 59:141-149

Mubarak M, Salem EMM, Kenawey MKM, Saudy HS (2021) Changes in calcareous soil activity, nutrient availability, and corn productivity due to the integrated effect of straw mulch and irrigation regimes. J Soil Sci Plant Nutr 21:2020-2031. https://doi.org/10. 1007/s42729-021-00498-w

Nam S, Kang S, Kim J (2020) Maintaining a constant soil moisture level can enhance the growth and phenolic content of sweet basil better than fluctuating irrigation. Agric Water Manag 238:106203

Nawaz F, Ahmad R, Ashraf MY, Waraich EA, Khan SZ (2015) Effect of selenium foliar spray on physiological and biochemical processes and chemical constituents of wheat under drought stress. Ecotoxicol Environ Saf 113:191-200

Nezami A, Khazaei HR, Rezazadah ZB, Hosseini A (2008) Effects of drought stress and defoliation on sunflower (Helianthus annuus L) in controlled conditions. Desert 12:99-104

Ozturk M, Turkyilmaz Unal B, García-Caparrós P, Khursheed A, Gul A, Hasanuzzaman M (2021) Osmoregulation and its actions during the drought stress in plants. Physiol Plant 172:1321-1335. https://doi.org/10.1111/ppl.13297

Park SH, Lee BR, La VH, Mamun A, Bae DW, Kim TH (2021) Characterization of salicylic acid- and abscisic acid-mediated photosynthesis, $\mathrm{Ca}^{2+}$ and $\mathrm{H}_{2} \mathrm{O}_{2}$ accumulation in two distinct phases of drought stress intensity in Brassica napus. Environ Exp Bot 186:104434

Pokhrel Y, Felfelani F, Satoh Y, Boulange J, Burek P, Gädeke A, Gerten D, Gosling SN, Grillakis M, Gudmundsson L, Hanasaki N, Kim H, Koutroulis A, Liu J, Papadimitriou L, Schewe J, Schmied HM, Stacke T, Telteu CE, Thiery W, Veldkamp T, Zhao F, Wada Y (2021) Global terrestrial water storage and drought severity under climate change. Nat Clim Chang 11:226-233

Poór P, Gémes K, Horváth F, Szepesi Á, Simon ML, Tari I (2011) Salicylic acid treatment via the rooting medium interferes with stomatal response, $\mathrm{CO}_{2}$ fixation rate and carbohydrate metabolism in tomato, and decreases harmful effects of subsequent salt stress. Plant Biol 13:105-114. https://doi.org/10.1111/j.1438-8677.2010. 00344.x

Salem EMM, Kenawey MKM, Saudy HS, Manal Mubarak (2022) Influence of silicon forms on nutrient accumulation and grain yield of wheat under water deficit conditions. Gesunde Pflanzen. https://doi.org/10.1007/s10343-022-00629-y

Salem EMM, Kenawey MKM, Saudy HS, Mubarak M (2021) Soil mulching and deficit irrigation effect on sustainability of nutrients availability and uptake, and productivity of maize grown in calcareous soils. Commun Soil Sci Plant Anal 52:1745-1761. https:// doi.org/10.1080/00103624.2021.1892733
Saudy HS, El-Metwally IM (2019) Nutrient utilization indices of NPK and drought management in groundnut under sandy soil conditions. Commun Soil Sci Plant Anal 50:1821-1828. https://doi.org/ 10.1080/00103624.2019.1635147

Saudy HS, El-Bially M, El-Metwally IM, Shahin MG (2021) Physiobiochemical and agronomic response of ascorbic acid treated sunflower (Helianthus Annuus) grown at different sowing dates and under various irrigation regimes. Gesunde Pflanz 73:169-179. https://doi.org/10.1007/s10343-020-00535-1

Saudy HS, El-Metwally IM, Abd El-Samad GA (2020) Physiobiochemical and nutrient constituents of peanut plants under bentazone herbicide for broad-leaved weed control and water regimes in dry land areas. J Arid Land 12:630-639. https://doi. org/10.1007/s40333-020-0020-y

Shemi R, Wang R, Gheith ESMS, Hussain HA, Hussain S, Irfan M, Cholidah L, Zhang K, Zhang S, Wang L (2021) Effects of salicylic acid, zinc and glycine betaine on morpho-physiological growth and yield of maize under drought stress. Sci Rep 11:1-14

Siddique MS, Qadir G, Gill SM, Sultan T, Ahmed ZI, Hayat R (2020) Bio-invigoration of rhizobacteria supplemented with exogenous salicylic acid and glycine betaine enhanced drought tolerance in sunflower. Intl J Agric Biol 23:869-881

Smith SM, Li C, Li J (2017) Hormone function in plants. In: Li J, Li C, Smith SM (eds) Hormone metabolism and signaling in plants. Academic Press, New York, pp 1-32

Souri MK, Hatamian M (2019) Aminochelates in plant nutrition, a review. J Plant Nutr 42:67-78

Souri MK, Hatamian M, Tesfamariam T (2019) Plant growth stage influences heavy metal accumulation in leafy vegetables of garden cress and sweet basil. Chem Biol Technol Agric. https://doi.org/ 10.1186/s40538-019-0170-3

Taha R, Alharby H, Bamagoos A, Medani R, Rady M (2020) Elevating tolerance of drought stress in Ocimum basilicum using pollen grains extract; a natural bio stimulant by regulation of plant performance and antioxidant defense system. S Afr J Bot 128:42-53

Tahjib-Ul-Arif M, Siddiqui MN, Sohag AAM, Sakil MA, Rahman MM, Polash MAS, Mostofa MG, Tran LSP (2018) Salicylic acid-mediated enhancement of photosynthesis attributes and antioxidant capacity contributes to yield improvement of maize plants under salt stress. J Plant Growth Regul 37:1318-1330. https://doi.org/10.1007/s00344-018-9867-y

Vermeirer L, Jopling GA (1984) Localized irrigation. Irrigation paper, vol 36. FAO, Rome

Yawson DO, Bonsu M, Armah FA, Afrifa EKA (2011) Water requirement of sunflower (Helianthus annuus L) in a tropical humid-coastal savanna zone ARPN. J Agric Biol Sci 4:1-8

You J, Chan Z (2015) ROS regulation during abiotic stress responses in crop plants. Front Plant Sci 6:1092. https://doi.org/10.3389/fpls. 2015.01092

Zulfiqar F, Ashraf M (2021) Bioregulators: Unlocking their potential role in regulation of the plant oxidative defense system. Plant Mol Biol 105:11-41

Zulfiqar F, Hancock JT (2020) Hydrogen sulfide in horticulture: Emerging roles in the era of climate change. Plant Physiol Biochem 155:667-675

Zulfiqar F, Chen J, Finnegan PM, Younis A, Nafees M, Zorrig W, Hamed KB (2021) Application of trehalose and salicylic acid mitigates drought stress in sweet basil and improves plant gowth. Plants 10:1078. https://doi.org/10.3390/plants10061078

Hani S. Saudy (PhD) was born in Giza, Egypt, in 1973. He is Professor at the Agronomy Department, Faculty of Agriculture, Ain Shams University, Egypt. He is a specialist in Field Crop Physiology and Management. His specific research area focused on Weed Ecology \& Management particularly in field crops. He is interested in using natural products for clean agriculture and organic farming. 